\title{
Kerosene poisoning in children in Iraq
}

\author{
NA Nagi, ZA Abdulallah
}

\begin{abstract}
Summary
One hundred and three children with kerosene poisoning were studied. The majority of the patients were under five years of age and included a newborn baby. More patients were seen in spring and fewer in winter months. Most of the patients were children of poor families living in overcrowded conditions. Negligence and ignorance were the main causes of poisoning. Respiratory and central nervous systems were mainly involved. Chest X-ray abnormalities were frequently seen. The patients were treated symptomatically. Only one patient died, he had been in a coma on admission to the hospital. All other patients had rapid and complete recoveries
\end{abstract}

Keywords: kerosene poisoning, children, Iraq

\section{Introduction}

Accidental poisoning is an important cause of death in early childhood. Hydrocarbon ingestions account for about $5 \%$ of all accidental poisonings and $25 \%$ of all fatal ingestions in children of less than five years of age. ${ }^{1,2}$

Kerosene is a hydrocarbon product of petroleum distillate, made up of paraffin and naphthenes. In developing countries kerosene is commonly kept in the home, being extensively used for cooking, heating and lighting. Consequently accidental kerosene ingestion is often seen in children in these countries. Such children are usually admitted to hospital for observation and treatment. Kerosene toxicity involves mainly the respiratory and central nervous systems. The gastro-intestinal tract is also commonly but mildly involved. Rarely, other systems may be affected such as the kidneys and myocardium. ${ }^{3} \mathrm{~A}$ prospective study was carried out on kerosene poisoning at $\mathrm{Al}$ Khansa Children's Hospital in the city of Mosul, in the north of Iraq. The aims of the study were to identify the epidemiological profile of affected children, to describe clinical presentation and to arrive at recommendations on preventive measures and optimal management. The study period covered two years and included 103 patients.

Department of

Paediatrics, College of Medicine, University of Mosul, Iraq NA Nagi

ZA Abdulallah
The study ran from 1 January 1991 to 31 December 1992 and included all patients who were admitted to the Al-Khansa Children's
Hospital with a history of kerosene ingestion. The history was given by the parents. Patients were examined in the emergency ward soon after their arrival at the hospital. A chest X-ray, complete blood picture and urinalysis were performed for each patient within 24 hours of admission.

\section{Results}

The number of patients was 103, of these 65 were boys. A male preponderance is usual with kerosene and other poisonings and accidents. ${ }^{4}$ The age distribution of the patients is shown in box 1; the majority were under five years. A seven-day-old baby is included in this series. To the best of our knowledge this is the youngest patient to be reported with kerosene poisoning. A clinical description of the newborn baby is given in box 2 .

SEASON

The monthly incidence during the two years of the study is shown in the figure. More patients were seen in spring and fewer in winter. This is because during cold weather the children are kept indoors with the rest of the family.

\section{Case report}

A 7-day-old female breast-fed baby was admitted to Al-Khansa hospital with convulsions. She was the product of a normal pregnancy and delivery and had been well until the day of admission, when she suffered from poor feeding, irritability and convulsions. For about six hours before admission to the hospital her anterior chest wall had been covered with a wide piece of kerosene-soaked cloth placed there by her fiveyear-old sister. This was not noticed or recognised by their mother. On examination at the hospital the covered part of the chest wall was intensely red with several bullae, some having ruptured. The rest of the examination was normal; blood culture showed no bacterial growth and the chest $\mathrm{X}$-ray was normal. Investigations revealed normal blood sugar, calcium and electrocytes. Cerebrospinal fluid was normal. Whilst in the hospital she suffered several attacks of generalised prolonged convulsions. She did not respond to parenteral vitamin B6. The convulsions partially responded to anticonvulsant therapy including diazepam, phenobarbitone and paraldehyde. Convulsions stopped after 24 hours from the time of admission without further anti-convulsant therapy. Our diagnosis was kerosene intoxication through skin absorption. Follow-up revealed a healthy child with normal growth and development 


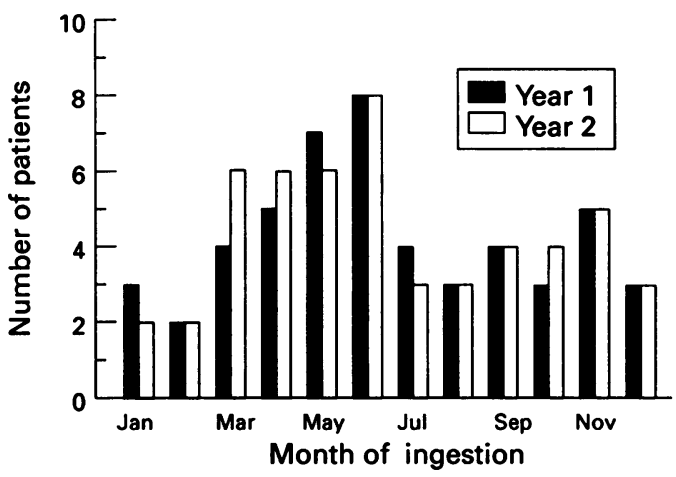

Figure Seasonal incidence of kerosene ingestion in 103 children over a two-year period

\section{SOCIOECONOMIC STATUS}

Over $75 \%$ of the patients were from poor families, living in crowded conditions where kerosene is used extensively and where care and supervision of children are suboptimal.

\section{KEROSENE STORAGE}

It is unfortunate that kerosene is usually stored in unlocked and exposed containers. Containers are placed on the floor, in the vicinity of the play areas, within easy reach of infants and toddlers. As with other studies improper storage was found to be the main cause of poisoning. ${ }^{4-6}$

\section{CLINICAL MANIFESTATIONS}

Manifestations of the poisoning are shown in the table and in box 3 . Over $90 \%$ of the patients in this study had symptoms relating to the respiratory system (coughing, tachypnoea, cyanosis and grunting). Previous studies have also revealed symptomatic involvement of the respiratory system to be a common complication of hydrocarbon ingestion. ${ }^{1,2,4}$

\section{NERVOUS SYSTEM}

The central nervous sytem (CNS) was involved in over a third of patients in the present study with wide variations in presentation. Some patients showed only restlessness, in others convulsions and/or coma were seen. Past reports reveal CNS involvement to be common and second only to respiratory complications. ${ }^{4,7}$ Wasserman ${ }^{8}$ mentions a variety of neurological

Table Clinical manifestations of kerosene ingestion among 103 children

\begin{tabular}{lrr}
\hline & \multicolumn{2}{c}{ Patients } \\
Symptom & $n$ & $(\%)$ \\
\hline fever & 76 & $(73.8)$ \\
vomiting & 62 & $(60.2)$ \\
coughing & 86 & $(83.5)$ \\
tachypnoea & 53 & $(51.5)$ \\
cyanosis & 8 & $(7.8)$ \\
grunting & 3 & $(2.9)$ \\
restlessness & 30 & $(29.1)$ \\
drowsiness & 22 & $(21.4)$ \\
coma & 7 & $(6.8)$ \\
convulsion & 6 & $(5.8)$ \\
abdominal pain & 15 & $(14.6)$ \\
constipation & 30 & $(29.1)$ \\
diarrhoea & 10 & $(9.7)$ \\
\hline
\end{tabular}

\begin{tabular}{|l|}
\hline Typical clinical features of kerosene \\
overdose \\
\hline - coughing \\
- vomiting \\
- tachypnoea \\
- restlessness \\
- abdowiness \\
- fever \\
\hline
\end{tabular}

Box 3

abnormalities with hydrocarbon ingestion including lightheaciedness, dizziness, euphoria, headache, visual disturbances, impaired memory, seizures, coma, and respiratory paralysis. The aetiology of neurological manifestations is not clear, hypoxia has been suggested as the cause. $^{9}$

\section{GASTRO-INTESTINAL SYSTEM}

Complaints relating to the gastro-intestinal system were common among our patients and usually mild, including vomiting, diarrhoea, constipation and abdominal pain. Similar gastro-intestinal problems have been reported. ${ }^{4,10}$ Truemper et $a l^{11}$ attribute gastrointestinal symptoms to mucosal irritation.

\section{FEVER}

Fever is frequently seen with kerosene poisoning and may persist for several days. ${ }^{4,10}$ Seventy-six patients in this study had fever and there was correlation between the extent of lung involvement and the severity and duration of the fever.

\section{INVESTIGATIONS}

A complete blood picture in the present series demonstrated leukocytosis above $15 \times 10^{9} / 1$ in $25 \%$ of patients. Varying degrees of leukocytosis have been reported among patients with hydrocarbon ingestion. ${ }^{4,5,12}$

Urinalysis revealed albuminuria in three, glycosuria in two and both in one. In 71 cases Olstad and Lord ${ }^{13}$ encountered albuminuria in 21, glycosuria in 15 and both in seven, while Nori and Al-Rahim ${ }^{4}$ encountered one with albuminuria and one with glycosuria among 40 patients who had urinalysis.

\section{CHEST X-RAY}

All patients had a chest X-ray on admission to the hospital, of these 51 were normal and 52 considered abnormal. Abnormalities were mostly in the form of infiltrate. Consolidation was seen in seven and pleural effusion in two. Lower lobes were involved more than the upper ones. Lesions were right-sided in $45 \%$, left-sided in $33 \%$ and bilateral in $20 \%$. Patients with normal chest X-rays had milder illness.

Abnormalities in chest X-rays in this study were similar to those reported by Nori and Al-Rahim ${ }^{4}$ in that lesions were mostly bronchopneumonic in appearance. A variety of radiological abnormalities have been reported after hydrocarbon ingestion, including pleural effusion, pneumothorax, pneumomedias- 
tinum, subcutaneous emphysema, and pneumopericardium. ${ }^{14-16}$ Bergeson et al ${ }^{17}$ reported 15 cases with pneumatocoeles while Akumuguma and Odita ${ }^{6}$ reported air on oesophagogram in $23 \%$, gaseous distension of the stomach in $25 \%$ and cardiomegaly in $20 \%$ of their patients.

\section{Treatment}

Our patients were treated symptomatically. Oxygen, intravenous fluid, anticonvulsants and antipyretics were used as needed. Penicillin was given to 30 patients unnecessarily. Steriods were not used in this study. It is safest not to evacuate the stomach. Gastric lavage and emesis are of no value in this situation and are contraindicated in most cases. ${ }^{10,18,19}$ Thorough washing of contaminated skin and hair is important. ${ }^{3}$ This is well illustrated in the newborn baby in whom serious toxicity occurred through contamination of the skin (box 2). Among our patients recovery was rapid and without complication; only one patient died, who had been in deep coma on admission. A literature review of long-term follow-up of children with hydrocarbon poisoning shows absence of residual effects with complete resolution of radiological findings and normal pulmonary function several years postingestion. ${ }^{2,20,21}$

\section{Discussion}

The toxicity of petroleum distillates depends on their physicochemical properties of volatility, viscosity, and surface tension. Products with high volatility, low viscosity and low surface tension are more likely to be aspirated and result in pulmonary injury. Lower viscosity promotes penetration into more distal airways and lower surface tension increases spread over a larger area of lung tissue. ${ }^{22}$ Volatile hydrocarbons may reach the CNS through the blood stream after inhalation or ingestion. ${ }^{9}$

It is usually difficult to be certain about the amount of kerosene that has been ingested by a child, because the amount stored is usually unknown and some is usually spilled. It has been estimated that most children drink less than $30 \mathrm{ml}$; accidental ingestion of more than $90 \mathrm{ml}$ occurs rarely. ${ }^{1,5,23-25}$ Symptoms and signs

1 Machado BO, Cross K, Snodgrass Wr. Accidental hydrocarbon ingestion cases telephoned to a regional poison center. bon ingestion cases telephoned to

2 Taussig LM, Castro E, Landau LI, et al. Pulmonary function 8-10 years after hydrocarbon pneumonitis. Clin Pediatrics 1977; 16: 57-9.

3 Arena JM, Hydrocarbon poisoning current management. Pediatr Ann 1987; 16: 879-83.

Nori L, Al-Rahim $K$. Kerosene poisoning in children Postgrad Med $\mathcal{f} 1970$; 46: 71-5.

Klein BL, Simon JE. Hydrocarbon poisonings. Pediatr Clin N Am 1986; 33: 411-8.

6 Akamaguma AI, Odita JC. Radiology of kerosene poisoning in young children. Ann Trop Pediatrics 1983; 3: 85-8.

Eade NR, Taussig LM, Marks MI. Hydrocarbo pneumonitis. Paediatrics 1974; 54: 531-6.

8 Wasserman GS. Hydrocarbon poisoning. Crit Care $Q 1982$ 4: 33-41.

9 Gerarde HW, Linden NJ. Toxicological studies on hydrocarbons. Arch Environ Health 1963; 6: 329-41.

10 Cachia EA, Fenech FF. Kerosene poisoning in children. Arch Dis Child 1964; 39: 502.

\section{Learning points/recommendations}

- a public education programme is needed in Iraq to warn that kerosene is harmful and toxic and to emphasise that no attempt should be made to induce vomiting with kerosene poisoning

- kerosene should be stored in locked containers

- kerosene containers should be kept out of reach of children and away from play areas

- gastric emptying by lavage or by medication should be avoided on admission to hospital

- the majority of patients require no specific treatment or therapy

Box 4

frequently follow ingestion and respiratory manifestations usually predominate. Pulmonary injury in kerosene ingestion is due to chemical pneumonia. ${ }^{78}$ It has been demonstrated clearly in animal experiments that pulmonary injury following ingestion results from aspiration and not from gastro-intestinal absorption. ${ }^{20,26-29}$ These conclusions are consistent with the clinical observation that manifestations rapidly follow ingestion. The gasping and choking which frequently accompany ingestion predispose to aspiration..$^{30}$ Vomiting, whether spontaneous or induced, increases the risk of aspiration, ${ }^{23}$ and adds to the severity of pneumonia. ${ }^{31}$ Following ingestion, there is little absorption from the gastro-intestinal tract to the systemic circulation. Mann et $a^{\beta 2} \mathrm{dem}-$ onstrated that after administering $15 \mathrm{ml} / \mathrm{kg}$ body weight into the stomach of baboons, minuscule amounts of kerosene were seen in the brain, heart, lung, liver, spleen, and kidneys at necropsy. Because only small amounts are ingested by children it is concluded that CNS manifestations seen with kerosene ingestion are due to hypoxia and acidosis from damage to the lungs and not due to systemic absorption. ${ }^{32,33}$ These findings are consistent with the clinical observations that significant CNS complications are usually seen in association with pulmonary manifestations. Our experience with the newborn baby is striking in that she had severe CNS manifestations and the route of the kerosene was judged to be systemic. She had no clinical evidence of hypoxia and her chest $\mathrm{X}$-ray was normal.

11 Truemper E, Rocha SRD, Atkinson SD. Clinical characteristics, pathophysiology and management of hydrocarbon ingestion case report and review of literature. Pediatr Emerg Care 1987; 31: 187-93.

12 Victoria MS, Nangia BS. Hydrocarbon poisoning: a review. Paediatr Emerg Care 1987; 3: 184.

13 Olstad RB, Lord RMN. Kerosene intoxication. Am $\mathcal{f}$ Dis Child 1952; 83: 446.

14 Capitano MA, Kirkpatric JA. The radiological aspects of air and food passages. In: Ferguson CF, Kendig EL, eds Disorders of respiratory tract in children. 2nd edn. Philadelphia: WB Saunders Co, 1972; Vol 2 pp 1350-1.

15 Levine ML, Mascia AV. Pulmonary diseases and anomalies of infancy and childhood. New York: Harper and Row, 1966; p 197.

16 Perlich MM. Pulmonary diseases caused by chemical and physical agents. In: Baum ed. Textbook of pulmonary diseases. Boston: Little Brown \& Co. 1965; p 369.

17 Bergeson PS, Hales SW, Lustgarten MD, Lipow HW. Pneumatoceles following hydrocarbon ingestion. Am $\mathfrak{f}$ Dis Child 1975; 129: 49-54. 
$18 \mathrm{Ng}$ RC. Using syrup of Ipecae for ingestion of petroleum distillates. Pediatr Ann 1977; 6: 709.

$19 \mathrm{Ng} \mathrm{RC}$, Darwish H, Stewart DA. Emergency treatment of petroleum distillates and turpentine ingestine. Can Med Assoc $₹$ 1974; 111: 537 .

20 Gerarde HW. Toxicological studies in hydrocarbons kerosene. Toxicol Appl Pharmacol 1959; 1: 462.

21 Graham JR. Pneumonitics following aspiration of crude oil and its treatment by steroid hormones. Trans Am Clin and its treatment by steroid horm

22 Ervin ME. Petroleum distillates and turpentine. In: Haddad LM, Winchester JF, eds Clinical management of poisoning LM, Winchester JF, eds Clinical management of poisoning
and drug overdose. Philadelphia: WB Saunders Co, 1983; ch and

23 Press E, Adams WC, Chittenden RF. Co-operative kerosene poisoning study: evaluation of gastric lavage. Paediatrics 1962; 29: 648 .

24 Anas N, Namasonthi V, Ginsburg CM. Criteria for hospitalizing children who have ingested products containing hydrocarbons. $\mathcal{F} A M A$ 1981; 246: 840 .

25 Watson WA, Bradford DC, Veltri JC. The volume of a swallow. Am ₹ Emerg Med 1983; 1: 278 .
26 Bratton L, Haddow JE. Ingestion of charcoal lighter fluid. $\mathcal{f}$ Paediatr 1975; 87: 633 .

27 Dice WH, Ward G, Kelley J. Pulmonary toxicity following gastro intestinal ingestion of kerosene. Ann Emerg Med 1982; 11: 136 .

28 Richardson JA, Pratt-Thomas HR. Toxic effects of varying doses of kerosene administered by different routes. $A m \mathcal{F}$ Med Sci 1951; 221: 531 .

29 Wolfe BM, Brodcur AE, Shiedds JB. The role of gastrointestinal absorption of kerosene in producing pneumonitis intestinal absorption of kerosene

30 Griffin JW, Daeshner C, Collins VP. Hydrocarbon pneumonitis following furniture polish ingestion. A report pneumonitis following furniture polis
of 15 cases. $\mathcal{P}$ Pediatr 1954; 45: 13 .

31 Foley JC, Dreyer NB, Soule AB, Wall E. Kerosene poisoning in young children. Radiology 1954; 62: 817

32 Mann MD, Pirie DJ, Wolfsdorf J. Kerosene absorption in primates. F Pediatr 1977; 91: 495.

33 Wolfsdorf J. Kerosene intoxication. An experimental approach to the etiology of CNS manifestations in primates. 7 Pediatr 1976; 88: 1637 .

\section{Medical Anniversary WILLIAM OSLER, 12 JULY 1849}

(Sir) William Osler (1849-1919) was born at Bond Head, Ontario, Canada, of English parents and was a son of the manse. He was christened William because he was born on William of Orange day. He was educated at Toronto and McGill Universities and at University College, London. He became a professor of medicine successively at McGill (1875), Philadelphia, Pennsylvania (1884), Johns Hopkins (1888) and Oxford (1905). His textbook 'The principles and practice of medicine' (1892) became a classic international bestseller. He helped to found the American Association of Physicians (1886) and the Quarterly fournal of Medicine (1908). He became FRCP (1884), FRS (1898) and received a baronetcy (1911). Harvey Cushing's 'The life of Sir William Osler' (1925) deservedly earned a Pulitzer prize. He will also be remembered by many eponyms; numerous honorary degrees as the greatest medical personality of his day; and Osler societies in London, USA, Japan and South Africa. He died from pneumonia on 30 December 1919 at his home 13 Norham Gardens, Oxford, UK, two years after the death of his only son, Revere, killed in Flanders. 